\title{
2015 Eberhard F. Mammen Award Announcements: Part II-Young Investigator Awards
}

\author{
Emmanuel J. Favaloro, PhD, FFSc (RCPA) ${ }^{1}$ \\ ${ }^{1}$ Department of Haematology, Sydney Centres for Thrombosis and \\ Haemostasis, Institute of Clinical Pathology and Medical Research \\ (ICPMR), Westmead Hospital, Westmead, New South Wales, \\ Australia
}

Semin Thromb Hemost 2015;41:809-815.

Welcome to another of our Eberhard F. Mammen award announcements. As noted previously, ${ }^{1-3}$ Thieme, the publisher of Seminars in Thrombosis \& Hemostasis, has created the "Eberhard F. Mammen Excellence in Thrombosis and Hemostasis Awards" in honor of Eberhard F. Mammen, and in recognition of his contribution to this field and to the journal that he both founded and steered for over three decades. These awards began in 2009, under two categories; the current award details and conditions are as follows:

- Most popular article awards: Awarded to the authors of the most popular articles published in Seminars in Thrombosis \& Hemostasis. The awards are determined by the Editor in Chief on the basis of user statistics from Thieme e-Journals from the preceding 2 years. Prefaces, Errata, Letters to the Editor and Editorials, and previous award winners, are excluded from further consideration of these awards, which currently comprise two categories-one for "open access" articles, and another for a "General Category." There are two major cash prizes of US $\$ 1,000$ for each category. In addition, winners of the "General Category" awards are granted "open access" status of these articles thereafter.

- Young investigator awards: Best presentation or meeting abstract by a young investigator-as presented or delivered to an international or large regional meeting on a topic related to the fields of thrombosis and hemostasis, and whose subject matter is determined to be in the spirit of Dr. Mammen. Up to six cash prizes of US $\$ 1,000$ are awarded in any year. There are some additional considerations and conditions for the award, and awardees are expected to prepare a review or other article related to the topic of their presentation (or as otherwise agreed) for publication in Seminars in Thrombosis \& Hemostasis.

Address for correspondence Emmanuel J. Favaloro, PhD, FFSc (RCPA), Sydney Centres for Thrombosis and Haemostasis, Department of Haematology, Institute of Clinical Pathology and Medical Research (ICPMR), Westmead Hospital, Westmead, New South Wales, 2145, Australia (e-mail: emmanuel.

favaloro@health.nsw.gov.au).
Further details of the awards and the award winners are posted online (available at: http://www.thieme. com/sth), and previous award winner announcements are also available in print. ${ }^{4-12}$

The winners of the 2015 Eberhard F. Mammen awards for the most popular articles from Seminars in Thrombosis $\mathcal{E}$ Hemostasis for the period of 2012 to 2013 inclusive were announced in an earlier issue. ${ }^{12}$ It is therefore with great pleasure that we would like to announce the winners of the 2015 Young Investigator awards related to meetings held in the recent past.

\section{Young Investigator Awardees}

As mentioned above, the Young Investigator awards represent winners of the best presentation or meeting abstract by a young investigator-as presented or delivered to an international or large regional meeting on a topic related to the fields of thrombosis and hemostasis, and whose subject matter is determined to be in the spirit of Dr. Mammen. There are additional considerations given that the nominees' presentations are not always seen by all of the possible award nominators. The 2015 winners are identified below and also listed in - Table 1 . The six awardees were derived from a total of 16 nominees, seven from the DLSH 2015 meeting (18th International Meeting of the Danubian League Against Thrombosis and Haemorrhagic Disorders; May 14-16, 2015; Sarajevo) and 9 from the ISTH 2015 meeting (XXV Congress of the International Society on Thrombosis and Hemostasis; June 20-25, 2015; Toronto). A meeting report from the DLSH meeting is available elsewhere in this issue of the journal. $^{13}$
Copyright ( $\odot 2015$ by Thieme Medical Publishers, Inc., 333 Seventh Avenue, New York, NY 10001, USA.

Tel: +1(212) 584-4662.
DOI http://dx.doi.org/ 10.1055/s-0035-1565256. ISSN 0094-6176.
Hemophilia. Recognizing Clinic Heterogeneity, Replacement Therapy and Outcome Assessment; Guest Editor: Alok Srivastava, MD, FRACP, FRCPA FRCP. 
Table 1 Young Investigator Awardees (2015)

\begin{tabular}{|c|c|c|c|}
\hline Awardee & Current placement & Presentation(s) awarded & Meeting presented \\
\hline Juraj Sokol & $\begin{array}{l}\text { Jessenius Faculty of Medicine, } \\
\text { Martin, Slovakia }\end{array}$ & $\begin{array}{l}\text { Genetics of sticky platelet } \\
\text { syndrome and fetal loss }\end{array}$ & \multirow{3}{*}{$\begin{array}{l}\text { DLTH } 2015 \text { (18th International } \\
\text { Meeting of the Danubian } \\
\text { League Against Thrombosis } \\
\text { and Haemorrhagic Disorders; } \\
\text { May 14-16, 2015; Sarajevo) }\end{array}$} \\
\hline Ljubica Jovanović & $\begin{array}{l}\text { Emergency Cardiology, Emer- } \\
\text { gency Center, Clinical Center of } \\
\text { Serbia, Belgrade }\end{array}$ & $\begin{array}{l}\text { Practical aspects of monitoring } \\
\text { of antiplatelet therapy }\end{array}$ & \\
\hline Lucia Stanciakova & $\begin{array}{l}\text { National Center of Hemostasis } \\
\text { and Thrombosis, Clinic of Hema- } \\
\text { tology and Transfusiology, Martin } \\
\text { University Hospital, Slovakia }\end{array}$ & $\begin{array}{l}\text { Rotational thromboelastome- } \\
\text { try and monitoring of antico- } \\
\text { agulation in pregnant women } \\
\text { with increased risk of fetal loss }\end{array}$ & \\
\hline Tina Biss & $\begin{array}{l}\text { Newcastle upon Tyne Hospitals } \\
\text { NHS Foundation Trust, and Insti- } \\
\text { tute of Cellular Medicine, New- } \\
\text { castle University, United Kingdom }\end{array}$ & $\begin{array}{l}\text { Venous thromboembolism } \\
\text { occurring during adolescence: } \\
\text { is it preventable? }\end{array}$ & \multirow[t]{3}{*}{$\begin{array}{l}\text { ISTH } 2015 \text { (XXV Congress of } \\
\text { the International Society on } \\
\text { Thrombosis and Hemostasis; } \\
\text { June } 20-25,2015 \text {; Toronto) }\end{array}$} \\
\hline Tobias Fuchs & $\begin{array}{l}\text { University Medical Center } \\
\text { Hamburg-Eppendorf, Institute of } \\
\text { Clinical Chemistry and Laboratory } \\
\text { Medicine, Hamburg, Germany, } \\
\text { and Karolinska Institute, Depart- } \\
\text { ment of Molecular Medicine and } \\
\text { Surgery, Stockholm, Sweden }\end{array}$ & $\begin{array}{l}\text { DNA in plasma indicates } \\
\text { disease extent and predicts } \\
\text { mortality in patients with } \\
\text { venous thromboembolism }\end{array}$ & \\
\hline Jonathan M. Coutinho & $\begin{array}{l}\text { Toronto Western Hospital, } \\
\text { University of Toronto, Canada }\end{array}$ & $\begin{array}{l}\text { Is anemia a risk factor for } \\
\text { cerebral venous thrombosis? }\end{array}$ & \\
\hline
\end{tabular}

Dr. Juraj Sokol (-Fig. 1) is postdoctoral researcher at Jessenius Faculty of Medicine in Martin, Slovakia. He received his MD and PhD from Jessenius Faculty of Medicine in Martin, respectively, in 2010 and 2014. He is currently in a clinical training program for Hematology and Transfusion Medicine. In 2014, Dr. Sokol founded a civic organization "Young Haematologists" with several colleagues. The primary mis-

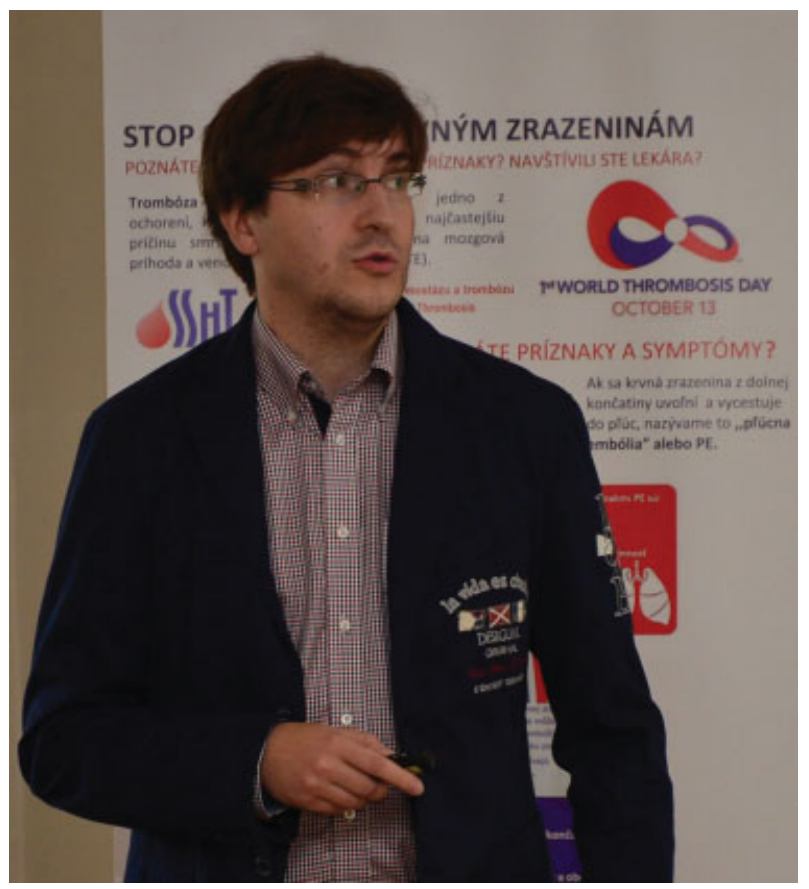

Fig. 1 Young Investigator Award winner Dr. Juraj Sokol. sion of this organization is to give young hematologists in training the opportunity to present their scientific works at a national level. Dr. Sokol holds the most prestigious awards for young scientists in Slovakia (Guoth price from the Presidium of the Slovak Medical Association and Student Personality of Slovakia of the Year 2013 award in medical sciences and pharmacy). His research interests include: recurrent pregnancy loss, maternal thrombophilias, and thrombosis. He is author or coauthor of more than 120 professional and scientific publications.

Dr. Ljubica Jovanović (-Fig. 2) is a clinical doctor at the department of emergency cardiology at the Emergency Center, Clinical Center of Serbia, Belgrade. She graduated from the School of Medicine, University of Belgrade in 2011, and is currently undertaking PhD studies in Cardiology, as well as embarking on specialization in internal medicine, and is one of the youngest of our awardees. She has given several lectures in the field of hemostasis and cardiology at the national and regional-international congresses and is a member of several scientific societies. Dr. Jovanovic actively participates in several clinical trials, and has published several articles in peer-reviewed journals.

Dr. Lucia Stanciakova (-Fig. 3) received her medical degree from Jessenius Faculty of Medicine in Martin, Comenius University in Bratislava, Slovakia in 2013, and so is the youngest of the Eberhard F. Mammen Young Investigator award winners. She has been working as a postgraduate student at the National Center of Hemostasis and Thrombosis, Clinic of Hematology and Transfusiology at the Martin University Hospital in Slovakia, with a special interest in the field of hemostasis and thrombosis. She is a member of the Slovak Society for Haemostasis and Thrombosis and in charge of the 


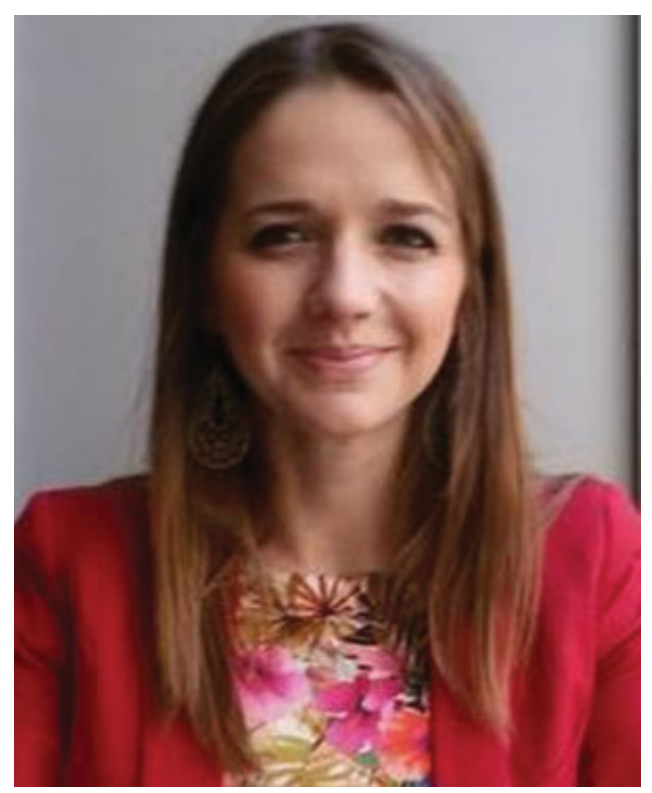

Fig. 2 Young Investigator Award winner Dr. Ljubica Jovanović.

comanagement of the National Registry of Thrombophilic States in Slovakia. She is focused especially on inherited and acquired thrombophilia, but also on anticoagulation in highrisk pregnancy or on the issues influencing the quality of life of patients with bleeding disorders, such as inhibitor development in hemophilia, diagnostics of von Willebrand disease, and the management of patients with rare bleeding disorders.

Dr. Tina Biss (-Fig. 4) is a Consultant in Hemostasis and Thrombosis at Newcastle upon Tyne Hospitals NHS Foundation Trust and also an Associate Clinical Researcher for the Institute of Cellular Medicine, Newcastle University, United Kingdom. She received her medical degree in 1997 from Nottingham University Medical School, United Kingdom and trained in General Medicine and Hematology. In 2007,

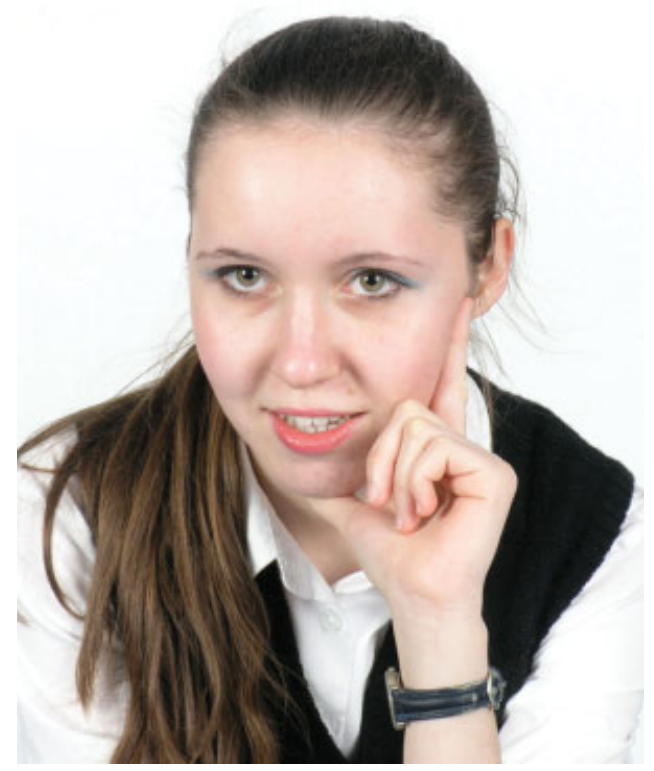

Fig. 3 Young Investigator Award winner Dr. Lucia Stanciakova.

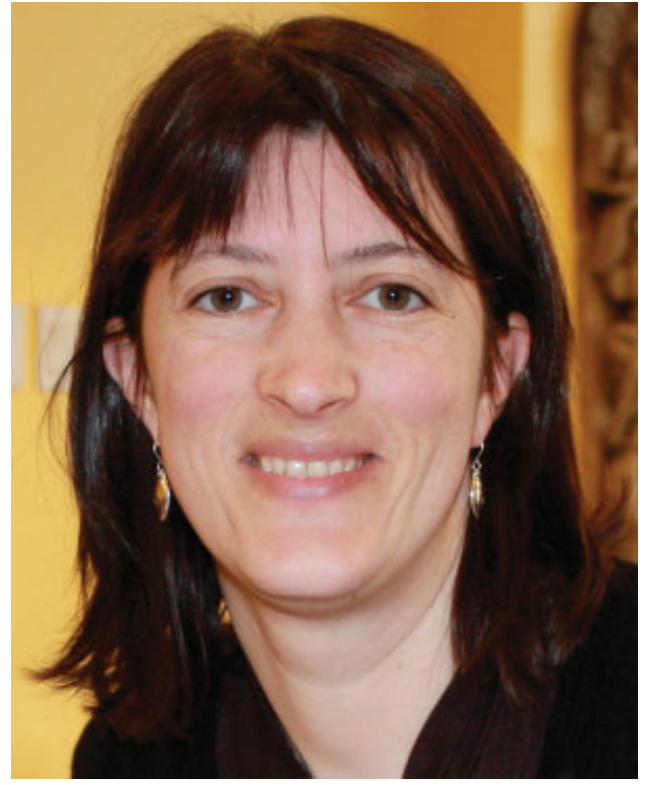

Fig. 4 Young Investigator Award winner Dr. Tina Biss.

she completed a fellowship in Pediatric Thrombosis and Hemostasis at the Hospital for Sick Children, Toronto. During this fellowship, under the mentorship of Prof. Margaret Rand and Dr. Suzan Williams, she investigated the utility of the Pediatric Bleeding Questionnaire in the diagnosis of von Willebrand disease and the clinical characteristics of pulmonary embolism in children. In 2011, she was awarded a postgraduate research degree for her thesis on the influence of pharmacogenetic factors on warfarin response in children. Her primary clinical and research interest is in pediatric thrombosis and anticoagulation.

Dr. Tobias Fuchs (- Fig. 5) is an assistant professor and head of the laboratory of molecular inflammation in the Institute of Clinical Chemistry and Laboratory Medicine at the University Medical Center Hamburg-Eppendorf. Dr. Fuchs received his $\mathrm{PhD}$ in Immunology, working under Dr. Arturo Zychlinsky, at the Max Planck Institute for Infection Biology in Berlin. For his postdoctoral fellowship, he joined the laboratory of Dr. Denisa Wagner at Harvard Medical School in Boston, United States. His research is centered around Neutrophil Extracellular

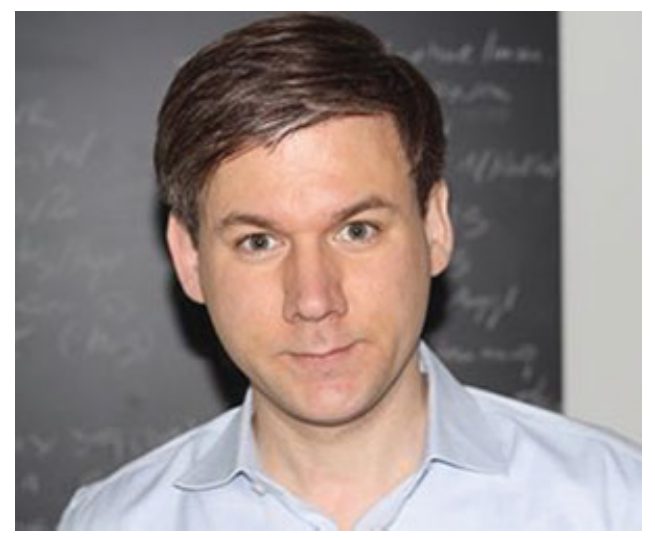

Fig. 5 Young Investigator Award winner Dr. Tobias Fuchs. 


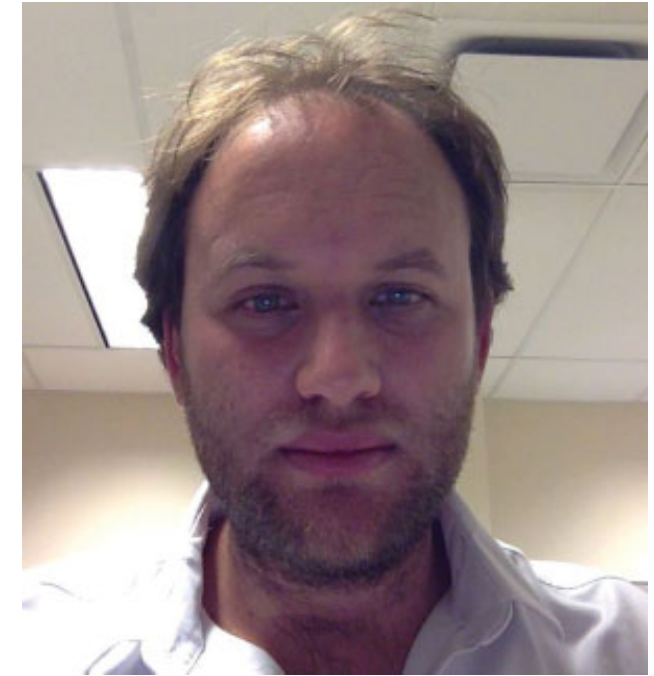

Fig. 6 Young Investigator Award winner Dr. Jonathan Coutinho.

Traps and supported by the Marie Curie Actions, the German Research Foundation, and the Foundation for Pathobiochemistry and Molecular Diagnostics.

Dr. Jonathan Coutinho (-Fig. 6) is a stroke neurologist from the Academic Medical Center in Amsterdam, The Netherlands. He completed his $\mathrm{PhD}$ on cerebral venous thrombosis in the spring 2014 under the supervision of Prof. Jan Stam. Thereafter, Dr. Coutinho spent a year at the University of Toronto as a postdoctoral research fellow. He is involved in a variety of international clinical studies on cerebral venous thrombosis, including principal investigator of the TO-ACT trial (thrombolysis or anticoagulation for cerebral venous thrombosis). His other main research interest is the treatment of acute ischemic stroke.

All award winners were thrilled to hear that they had been selected to receive an Eberhard F. Mammen Young Investigator award, and provided the following additional commentary:

It is with deepest appreciation that I express my thanks for being chosen as a recipient of the 2015 Eberhard F. Mammen Young Investigator award. To be nominated and then recognized with this award was an unexpected honor for which I am very grateful. However, I feel that this award recognizes not just my efforts, but also those of my colleagues. In particular, I wish to give a huge "thank you" to my supervisor Professor Peter Kubisz, for his unflagging support and ongoing advice.

$$
\text { -Juraj Sokol ( - Fig. 1) }
$$

I am very honored to have been selected for this prestigious award, being a young doctor interested in the challenging field of hemostasis and thrombosis. The main goal of my presentation was to provide a practical approach to the optimization and tailoring of antiplatelet therapy with the consideration of patient characteristics, with special concern of risk of bleeding and thrombosis. This award represents the recognition for the whole team of enthusiastic doctors in our Clinical Center of Serbia,
Belgrade, and I hope we will be able to continue to contribute our ongoing research to improve health care.

$$
\text { -Ljubica Jovanovic (-Fig. 2) }
$$

It is an infinite honor and great pleasure for me to receive one of the 2015 Eberhard F. Mammen Young Investigator awards. I would like to sincerely thank my marvelous family, expert colleagues from the National Center of Hemostasis and Thrombosis in Slovakia and the editorial board of Seminars in Thrombosis \& Hemostasis for this honor. I also thank all the people who continue to support my efforts to perform high-quality research and clinical studies, thus increasing our knowledge and helping our patients by improving their health care management. At our Slovak National Center of Hemostasis and Thrombosis I have the unique chance to participate in many projects, as we perform studies in various fields of thrombosis and hemostasis. Worldwide, the need for individualized thromboprophylaxis increases and studies focused on the extensive monitoring of hemostasis in pregnant women with thrombophilia are lacking. Therefore, with our research team we carefully follow-up the hemostatic parameters in this particular group of patients, who are at an increased risk of fetal loss and other pregnancy and thrombotic complications. Based on their results, we are immediately able to tailor their anticoagulant thromboprophylaxis. Finally, it is a great feeling for me to see the successful outcome-happy mother and healthy baby. In addition to such patient satisfaction and the positive effect of their treatment, this award provides me the motivation to continue in my enthusiasm into the future. I cordially hope to fulfill all future expectations.

$$
\text { -Lucia Stanciakova (-Fig. 3) }
$$

I am excited and honored to have received this award. My presentation was on the prevention of venous thromboembolism in adolescents and highlighted the need for further investigation into the efficacy and safety of mechanical and chemical thromboprophylaxis in this age group. I presented on behalf of a group of investigators from several large pediatric centers in the United Kingdom and I hope to continue to contribute to research in pediatric thrombosis and anticoagulation through the promotion of collaborative research within the United Kingdom and the wider research community.

-Tina Biss (-Fig. 4)

It is a great honor to receive the Eberhard F. Mammen Young Investigator award. This award is both a prestigious and practical means to supporting our research on neutrophil extracellular traps with the goal of developing novel diagnostic strategies for thromboembolic and cardiovascular diseases. I would like to thank the members of my laboratory, collaborators, and mentors who made this award possible.

-Tobias Fuchs (-Fig. 5)

I was surprised and honored to learn that I had been granted one of the 2015 Eberhard F. Mammen awards. Our study on the association between anemia and cerebral venous thrombosis was a collaborative effort between the 
Academic Medical Center, Amsterdam and Leiden University Center, and I want to extend my gratitude to my coauthors for all their efforts. Such collaborations are a prerequisite when studying a disease as rare as cerebral venous thrombosis.

$$
\text { -Jonathan Coutinho (-Fig. 6) }
$$

In keeping with last year's editorial, I decided to again review the Young Investigator awardees from previous years as well as the outcome of their subsequent submissions ${ }^{14-36}$ to Seminars in Thrombosis $\mathcal{E}$ Hemostasis, and as summarized in - Table 2. I previously mentioned my personal gratification that most of the articles from earlier years have subsequently appeared in several annual top 100 listings. ${ }^{9,10}$ of further interest, one of these articles actually won one of the Most
Popular awards in 2014 (within the open access Category) and based on the "most popular" 2012 to 2013 list. ${ }^{19}$ Also motivating is that a few of the Young Investigator awardees were also included as authors on other contributions to Seminars in Thrombosis $\mathcal{E}$ Hemostasis that were also listed in these most popular listings, including another 2014 Most Popular award winner. ${ }^{37}$

These findings certainly appear to validate the Young Investigator award process, and I look forward to seeing their careers continue to develop. The above also suggests that future Young Investigator awardees have a very high bar to jump, given the precedence identified for the earlier awardees.

I would like as always to congratulate the current Young Investigator awardees for their awards, and will also take the opportunity to thank previous Young Investigator awardees

Table 2 Young Investigator Awardees from previous years

\begin{tabular}{|c|c|c|}
\hline Awardee & $\begin{array}{l}\text { Year } \\
\text { awarded }\end{array}$ & Publication arising \\
\hline Willem M. Lijfering & 2009 & $\begin{array}{l}\text { Lijfering WM, Flinterman LE, Vandenbroucke JP, Rosendaal FR, Cannegieter SC. } \\
\text { Relationship between venous and arterial thrombosis: a review of the literature from } \\
\text { a causal perspective. Semin Thromb Hemost } 2011 ; 37(8): 885-896\end{array}$ \\
\hline Salley Pels & 2009 & $\begin{array}{l}\text { Pels SG. Current therapies in primary immune thrombocytopenia. Semin Thromb } \\
\text { Hemost } 2011 ; 37(6): 621-630\end{array}$ \\
\hline Adam Cuker & 2010 & $\begin{array}{l}\text { Cuker A. Current and emerging therapeutics for heparin-induced thrombocytope- } \\
\text { nia. Semin Thromb Hemost 2012;38(1):31-37 }\end{array}$ \\
\hline $\begin{array}{l}\text { Giridhara Rao } \\
\text { Jayandharan }\end{array}$ & 2010 & $\begin{array}{l}\text { Jayandharan GR, Srivastava A, Srivastava A. Role of molecular genetics in hemophilia: } \\
\text { from diagnosis to therapy. Semin Thromb Hemost 2012;38(1):64-78 }\end{array}$ \\
\hline Timea Szanto & 2010 & $\begin{array}{l}\text { Szántó T, Joutsi-Korhonen L, Deckmyn H, Lassila R. New insights into von Willebrand } \\
\text { disease and platelet function. Semin Thromb Hemost 2012;38(1):55-63 }\end{array}$ \\
\hline Birgitta Salmela & 2010 & $\begin{array}{l}\text { Salmela B, Joutsi-Korhonen L, Armstrong E, Lassila R. Active online assessment of } \\
\text { patients using new oral anticoagulants: bleeding risk, compliance, and coagulation } \\
\text { analysis. Semin Thromb Hemost 2012;38(1):23-30 }\end{array}$ \\
\hline $\begin{array}{l}\text { Pia Riittaa-Maria } \\
\text { Siljander }\end{array}$ & 2010 & $\begin{array}{l}\text { Aatonen M, Grönholm M, Siljander PR. Platelet-derived microvesicles: multitalented } \\
\text { participants in intercellular communication. Semin Thromb Hemost 2012;38 } \\
\text { (1):102-113 }\end{array}$ \\
\hline Romaric Lacroix & 2011 & $\begin{array}{l}\text { Lacroix R, Dignat-George F. Microparticles: new protagonists in pericellular and } \\
\text { intravascular proteolysis. Semin Thromb Hemost 2013;39(1):33-39 }\end{array}$ \\
\hline Brad McEwen & 2011 & $\begin{array}{l}\text { McEwen BJ, Morel-Kopp MC, Chen W, Tofler GH, Ward CM. Effects of omega-3 } \\
\text { polyunsaturated fatty acids on platelet function in healthy subjects and subjects } \\
\text { with cardiovascular disease. Semin Thromb Hemost } 2013 ; 39(1): 25-32\end{array}$ \\
\hline Neil A. Goldenberg & 2011 & $\begin{array}{l}\text { Bernard TJ, Armstrong-Wells J, Goldenberg NA. The institution-based prospective } \\
\text { inception cohort study: design, implementation, and quality assurance in pediatric } \\
\text { thrombosis and stroke research. Semin Thromb Hemost } 2013 ; 39(1): 10-14\end{array}$ \\
\hline Vivien Chen & 2011 & $\begin{array}{l}\text { Chen VM. Tissue factor de-encryption, thrombus formation, and thiol-disulfide } \\
\text { exchange. Semin Thromb Hemost 2013;39(1):40-47 }\end{array}$ \\
\hline Joseph E. Italiano, Jr. & 2011 & $\begin{array}{l}\text { Italiano JE Jr. Unraveling mechanisms that control platelet production. Semin } \\
\text { Thromb Hemost 2013;39(1):15-24 }\end{array}$ \\
\hline Vivian Xiaoyan Du & $2012 / 2013$ & $\begin{array}{l}\text { Du VX, Huskens D, Maas C, Al Dieri R, de Groot PG, de Laat B. New insights into the role } \\
\text { of erythrocytes in thrombus formation. Semin Thromb Hemost 2014;40(1):72-80 }\end{array}$ \\
\hline Andrew Yee & $2012 / 2013$ & $\begin{array}{l}\text { Yee A, Kretz CA. Von Willebrand factor: form for function. Semin Thromb Hemost } \\
2014 ; 40(1): 17-27\end{array}$ \\
\hline Sarah O’Brien & $2012 / 2013$ & $\begin{array}{l}\text { O'Brien SH. Contraception-related venous thromboembolism in adolescents. Semin } \\
\text { Thromb Hemost 2014;40(1):66-71 }\end{array}$ \\
\hline
\end{tabular}


Table 2 (Continued)

\begin{tabular}{|c|c|c|}
\hline Awardee & $\begin{array}{l}\text { Year } \\
\text { awarded }\end{array}$ & Publication arising \\
\hline Veronica Flood & 2012/2013 & $\begin{array}{l}\text { Flood VH. Perils, problems, and progress in laboratory diagnosis of von Willebrand } \\
\text { disease. Semin Thromb Hemost 2014;40(1):41-48 }\end{array}$ \\
\hline Julie Tange & $2012 / 2013$ & $\begin{array}{l}\text { Tange JI, Grill D, Koch CD, et al. Local verification and assignment of mean normal } \\
\text { prothrombin time and International Sensitivity Index values across various instru- } \\
\text { ments: recent experience and outcome from North America. Semin Thromb Hemost } \\
2014 ; 40(1): 115-120\end{array}$ \\
\hline Kent Chapman & $2012 / 2013$ & $\begin{array}{l}\text { Chapman K, Yuen S. Therapy for thrombotic thrombocytopenia purpura: past, } \\
\text { present, and future. Semin Thromb Hemost } 2014 ; 40(1): 34-40\end{array}$ \\
\hline Andreas Tiede & 2014 & $\begin{array}{l}\text { Tiede A, Werwitzke S, Scharf RE. Laboratory diagnosis of acquired hemophilia A: } \\
\text { limitations, consequences, and challenges. Semin Thromb Hemost 2014;40(7):803- } \\
811\end{array}$ \\
\hline Wendy Lim & 2014 & $\begin{array}{l}\text { Lim W. Thrombotic risk in the antiphospholipid syndrome. Semin Thromb Hemost } \\
\text { 2014;40(7):741-746 }\end{array}$ \\
\hline Susana Nobre Fernandes & 2014 & $\begin{array}{l}\text { Fernandes S, Carvalho M, Lopes M, Araújo F. Impact of an individualized prophylaxis } \\
\text { approach on young adults with severe hemophilia. Semin Thromb Hemost 2014;40 } \\
\text { (7):785-789 }\end{array}$ \\
\hline Maria Elisa Mancuso & 2014 & $\begin{array}{l}\text { Mancuso ME, Fasulo MR. Thrombin generation assay as a laboratory monitoring tool } \\
\text { during by-passing therapy in patients with hemophilia and inhibitors. Semin Thromb } \\
\text { Hemost 2015; doi: } 10.1055 / \mathrm{s}-0035-1564842\end{array}$ \\
\hline Coen Maas & 2014 & $\begin{array}{l}\text { Tersteeg C, Fijnheer R, Deforche L, et al. Keeping von Willebrand factor under } \\
\text { control: Alternatives for ADAMTS13. Semin Thromb Hemost 2015; doi: 10.1055/ } \\
\text { s-0035-1564838 }\end{array}$ \\
\hline Riten Kumar & 2014 & $\begin{array}{l}\text { Kumar R, Dunn A, Carcao M. Changing paradigm of hemophilia management: } \\
\text { extended half-life factor concentrates and gene therapy. Semin Thromb Hemost } \\
\text { 2015; In press }\end{array}$ \\
\hline
\end{tabular}

for their contributions; these have obviously been well received by readers of this journal. I look forward to reading, and monitoring the future popularity, of the contributions from the latest group of Young Investigators!

\section{References}

1 Favaloro EJ. Editorial. Welcome to a Special Issue of Seminars in Thrombosis and Hemostasis-The Closing Issue for 2008. Semin Thromb Hemost 2008;34:693-696

2 Favaloro EJ. A tribute to Eberhard F. Mammen, M.D. (1930-2008). Semin Thromb Hemost 2008;34(8):703-707

3 Favaloro EJ. Editorial. Welcome to the first issue of Seminars in Thrombosis and Hemostasis for 2009. Semin Thromb Hemost 2009;35(1):1-2

4 Favaloro EJ. Editorial. Winners of the Inaugural Eberhard F. Mammen Award for Most Popular Article. Semin Thromb Hemost 2009; 35:587-590

5 Favaloro EJ. Editorial. 2009 Eberhard F. Mammen Young Investigator Award Winners. Semin Thromb Hemost 2010;36:469-470

6 Favaloro EJ. Winners of the 2010 Eberhard F. Mammen award for most popular article during 2008-2009. Semin Thromb Hemost 2010;36(7):685-692

7 Favaloro EJ. 2011 Eberhard F. Mammen award announcements. Semin Thromb Hemost 2011;37(5):431-439

8 Favaloro EJ. 2012 Eberhard F. Mammen award announcements. Semin Thromb Hemost 2012;38(5):425-432

9 Favaloro EJ. 2013 Eberhard F. Mammen award announcements. Semin Thromb Hemost 2013;39(6):567-574
10 Favaloro EJ. 2014 Eberhard F. Mammen award announcements: Part I-most popular articles. Semin Thromb Hemost 2014;40(4): 407-412

11 Favaloro EJ. 2014 Eberhard F. Mammen award announcements: part II-Young Investigator Awards. Semin Thromb Hemost 2014; 40(7):718-723

12 Favaloro EJ. 2015 Eberhard F. Mammen Award Announcements: Part I - most popular articles. Semin Thromb Hemost 2015;41(7): 673-679

13 Kubisz P, Mikovic D, Stanciakova L, Sinzinger H. Meeting report: 18th International Meeting of the Danubian League against Thrombosis and Haemorrhagic Disorders (DLTH). Semin Thromb Hemost 2015;41(8):903-906

14 Lijfering WM, Flinterman LE, Vandenbroucke JP, Rosendaal FR, Cannegieter SC. Relationship between venous and arterial thrombosis: a review of the literature from a causal perspective. Semin Thromb Hemost 2011;37(8):885-896

15 Pels SG. Current therapies in primary immune thrombocytopenia. Semin Thromb Hemost 2011;37(6):621-630

16 Cuker A. Current and emerging therapeutics for heparin-induced thrombocytopenia. Semin Thromb Hemost 2012;38(1): $31-37$

17 Jayandharan GR, Srivastava A, Srivastava A. Role of molecular genetics in hemophilia: from diagnosis to therapy. Semin Thromb Hemost 2012;38(1):64-78

18 Szántó T, Joutsi-Korhonen L, Deckmyn H, Lassila R. New insights into von Willebrand disease and platelet function. Semin Thromb Hemost 2012;38(1):55-63

19 Salmela B, Joutsi-Korhonen L, Armstrong E, Lassila R. Active online assessment of patients using new oral anticoagulants: bleeding risk, compliance, and coagulation analysis. Semin Thromb Hemost 2012;38(1):23-30 
20 Aatonen M, Grönholm M, Siljander PR. Platelet-derived microvesicles: multitalented participants in intercellular communication. Semin Thromb Hemost 2012;38(1):102-113

21 Lacroix R, Dignat-George F. Microparticles: new protagonists in pericellular and intravascular proteolysis. Semin Thromb Hemost 2013;39(1):33-39

22 McEwen BJ, Morel-Kopp MC, Chen W, Tofler GH, Ward CM. Effects of omega-3 polyunsaturated fatty acids on platelet function in healthy subjects and subjects with cardiovascular disease. Semin Thromb Hemost 2013;39(1):25-32

23 Bernard TJ, Armstrong-Wells J, Goldenberg NA. The institutionbased prospective inception cohort study: design, implementation, and quality assurance in pediatric thrombosis and stroke research. Semin Thromb Hemost 2013;39(1):10-14

24 Italiano JE Jr. Unraveling mechanisms that control platelet production. Semin Thromb Hemost 2013;39(1):15-24

25 Du VX, Huskens D, Maas C, Al Dieri R, de Groot PG, de Laat B. New insights into the role of erythrocytes in thrombus formation. Semin Thromb Hemost 2014;40(1):72-80

26 Yee A, Kretz CA. Von Willebrand factor: form for function. Semin Thromb Hemost 2014;40(1):17-27

27 O'Brien SH. Contraception-related venous thromboembolism in adolescents. Semin Thromb Hemost 2014;40(1):66-71

28 Flood VH. Perils, problems, and progress in laboratory diagnosis of von Willebrand disease. Semin Thromb Hemost 2014;40(1):41-48

29 Tange JI, Grill D, Koch CD, et al. Local verification and assignment of mean normal prothrombin time and International Sensitivity
Index values across various instruments: recent experience and outcome from North America. Semin Thromb Hemost 2014;40(1): $115-120$

30 Chapman K, Yuen S. Therapy for thrombotic thrombocytopenia purpura: past, present, and future. Semin Thromb Hemost 2014; 40(1):34-40

31 Tiede A, Werwitzke S, Scharf RE. Laboratory diagnosis of acquired hemophilia A: limitations, consequences, and challenges. Semin Thromb Hemost 2014;40(7):803-811

32 Lim W. Thrombotic risk in the antiphospholipid syndrome. Semin Thromb Hemost 2014;40(7):741-746

33 Fernandes S, Carvalho M, Lopes M, Araújo F. Impact of an individualized prophylaxis approach on young adults with severe hemophilia. Semin Thromb Hemost 2014;40(7):785-789

34 Mancuso ME, Fasulo MR. Thrombin generation assay as a laboratory monitoring tool during bypassing therapy in patients with hemophilia and inhibitors. Semin Thromb Hemost 2015; doi: $10.1055 / \mathrm{s}-0035-1564842$

35 Tersteeg C, Fijnheer R, Deforche L, et al. Keeping von Willebrand factor under control: Alternatives for ADAMTS13. Semin Thromb Hemost 2015; doi: 10.1055/s-0035-1564838

36 Kumar R, Dunn A, Carcao M. Changing paradigm of hemophilia management: extended half-life factor concentrates and gene therapy. Semin Thromb Hemost 2015; In press

37 Chapman K, Seldon M, Richards R. Thrombotic microangiopathies, thrombotic thrombocytopenic purpura, and ADAMTS-13. Semin Thromb Hemost 2012;38(1):47-54 